\title{
Copper activation option for a pentlandite-pyrrhotite- chalcopyrite ore flotation with nickel interest
}

\author{
I. O. Otunniyi ${ }^{1} \cdot$ M. Oabile ${ }^{1} \cdot$ A. A. Adeleke ${ }^{1} \cdot$ P. Mendonidis ${ }^{1}$
}

Received: 7 June 2015/Accepted: 17 May 2016/Published online: 30 May 2016

(c) The Author(s) 2016. This article is published with open access at Springerlink.com

\begin{abstract}
Introduction Different sulphide ores respond differently in the prospect of copper activation to thiols for froth flotation. With the BCL Selebi-Phikwe ore body, pentlanditepyrrhotite-chalcopyrite co-occur and there is the constraint of fine pentlandite dissemination in the pyrrhotite, so that liberation is limited. In the presence of pentlandite, pyrrhotite can even be galvanically depressed. In this scenario, response of the ore to copper activation may not be easily predicted. To explore the possibilities, flotation with various dosages of copper addition was investigated for this ore with specific interest in how the nickel recovery responds. The responses of copper, iron, cobalt and quartz were also monitored.

Result Increase in nickel recovery and grade with copper sulphate dosage was obtained, compared with no addition, but the trend showed a maxima after which depression was obtained. The optimum dosage in this instance was between 15 and $30 \mathrm{~g} /$ ton for best grade recovery. The response is understandable from the fact that the predominant copper species in the aqueous system can be ion or hydroxide depending on the concentration, among other factors. As ions the copper thus imparts activation, while as hydroxide it will cause depression. Pyrrhotite and chalcopyrite recovery also increased marginally along with the pentlandite.

Conclusion To achieve activation of pentlandite in the ore to thiol collector using copper sulphate, the dosage must be
\end{abstract}

I. O. Otunniyi

iyiolao@vut.ac.za

1 Metallurgical Engineering, Vaal University of Technology, Vanderbijlpark, South Africa about the optimum; higher dosages will bring about depression.

Keywords Froth flotation - Pentlandite - Pyrrhotite · Chalcopyrite $\cdot$ Copper sulphate activation

\section{Introduction}

The pentlandite-pyrrhotite-chalcopyrite ore body at SelebiPhikwe in Botswana has been mined by the BCL (Bamangwatu Concessions Limited) concentrator for the nickel and copper content since 1973. Various sources cite $0.55-0.71 \%$ $\mathrm{Ni}$ and $0.58-0.75 \% \mathrm{Cu}$ runoff mine grades, producing 2.5-3.5\% Ni and 3.2-4.5\% Cu concentrates [1-3]. The life of the mine has been projected differently to end by 2010 and 2014, but with deeper exploration and mining efforts, the life of the mine can be extended until $2024[4,5]$. In this further exploration, cutoff grade for resource reporting was put at $0.3 \% \mathrm{Ni}$ equivalent. The life of mine extension therefore comes with the challenge to increase production, grade and improved efficiency to maintain profitability beyond 2014 [5].

Record plant performance data show that nickel recoveries were about $85 \%$, but this dropped to values below $80 \%$ in the 1990s. Various efforts to improve recoveries include changes in the flotation circuits with the introduction of larger cell to increase residence time of slowfloating minerals; drum magnetic separator treatment of flotation tailings to recover weakly magnetic pyrrhotite containing finely disseminated target pentlandite; replacement of old rougher, scavenger and cleaner tanks at different times; automation of milling and flotation controls systems. The efforts restored recovery to $83-86 \%$ [2].

In these efforts, the chemistry was kept at the butyl xanthate collector with the generic frother, and surfactant 
suite modifications were not explored. The prospect of activation is considered worthy of investigation to make available more options for maximizing grade-recovery outcomes to prolong the mine life. For pentlandite activation to xanthates, the addition of copper, lead or silver can be recommended. Although the xanthate compound of any of these metals, having lower dissociation constants compared to that of nickel, will stabilize the surface xanthate product and enhance recovery, copper has been used mostly for many sulphide mineral beneficiation [6-8]. However, due to vast shades of variations in mineral occurrences from one deposit to another and even within the same ore body, response to well-known flotation schemes or reagents can vary widely [9]; hence, a conclusion pre-empting the response in this instance cannot be made without due investigations. The mineralogy of this ore body and the chemistry of $\mathrm{CuSO}_{4}$ interaction in the presence of co-occurring sulphides will have to be carefully considered.

The Selebi-Phikwe ore body consists of four co-occurring sulphide minerals-pentlandite, chalcopyrite, pyrite and pyrrhotite-along with other minerals, while the major gangues are amphibolites, quartz, mica and feldspar, forming typically about $68 \%$ (Table 1). Cobalt is present in solid solution in the pentlandite to about $0.05 \%$ head grade of the ore. In the presence of xanthate, sulphide minerals float favourably at different $\mathrm{pH}$ regimes; pyrrhotite in particular will float at a relatively lower $\mathrm{pH}$ compared to pentlandite, such that pentlandite can be selectively floated in pulps with sufficiently alkaline $\mathrm{pH}$ [10]. Differential flotation for these sulphides has been demonstrated where the natural floatability of chalcopyrite was enhanced by sulphur (IV) oxide with diethylenetriamine as the complexing agent, while pentlandite and pyrrhotite were depressed [11]. The depression was later reversed for pentlandite by xanthate addition to separate it from pyrrhotite. Using sodium isobutyl xanthate, the floatability of the sulphides obtained from Merensky ore was also shown to differ: highest for chalcopyrite and least for pyrrhotite [12]. This background apparently presents

Table 1 Representative mineral content of the BCL nickel-copper ore [1]

\begin{tabular}{llll}
\hline Mineral & Composition & Mass $\%$ & Contained \% Ni \\
\hline Pentlandite & $(\mathrm{FeNi})_{9} \mathrm{~S}_{8}$ & 1.7 & 0.61 \\
Chalcopyrite & $\mathrm{CuFeS}_{2}$ & 2.0 & - \\
Pyrrhotite & $\mathrm{Fe}_{7} \mathrm{~S}_{8}, \mathrm{Fe}_{9} \mathrm{~S}_{10}$ & 24.1 & 0.1 \\
Pyrite & $\mathrm{FeS}_{2}$ & 1.0 & 0.004 \\
Magnetite & $\mathrm{FeO}_{2} \mathrm{Fe}_{2} \mathrm{O}_{3}$ & 2.5 & - \\
Gangue & Various & 68.7 & 0.01 \\
Total & & 100 & 0.72 \\
\hline
\end{tabular}

the possibilities of exploring the rejection of the bulky pyrrhotite $(24.1 \%)$ and concentrate pentlandite and chalcopyrite (both only $3.7 \%$ ), but the pyrrhotite contains about $14 \%$ of the total nickel content in the ore, as can be inferred from the composition in Table 1. Rejecting the total pyrrhotite content therefore implies that the overall recovery will, by such process design, be capped below $86 \%$.

The other alternative is to liberate the pentlandite in the pyrrhotite before flotation, but the pentlandite values occur as 8-38 $\mu \mathrm{m}$ exsolution phase in the pyrrhotite, according to the mineral liberation analysis [1]. Grinding down to attain liberation will imply slime and entrainment issues. The option of fine grinding for liberation is therefore not available. From investigation of varying grinds down to $80 \%$ passing $75 \mu \mathrm{m}$, about $48 \%$ passing $75 \mu \mathrm{m}$ has been recommended for the operation [1]. On the other hand, activation is in a fix to activate pyrrhotite, and the outcome of the prospect is tied to how pyrrhotite will respond at the condition optimum for pentlandite flotation.

From various reports, the response of pyrrhotite to $\mathrm{CuSO}_{4}$ activation has been observed to differ among ore deposits, with recovery improvement ranging from $50 \%$ to insignificant [9, 13]. In a study of pyrrhotite from four providences, at $\mathrm{pH} 7, \mathrm{CuSO}_{4}$ was found to have no effect on sodium isobutyl xanthate (SIBX) recovery of Nkomati pyrrhotite, while Phoenix pyrrhotite showed a drop in recovery [9]. At $\mathrm{pH} 10$, the electrochemical impedance values at the surface of all the four pyrrhotite samples increased remarkably and SIBX could not float the samples. With $\mathrm{CuSO}_{4}$ addition, the recovery improved glaringly for three of the sulphides; from less than $10 \%$ to above $80 \%$ for Sudbury CNN and Phoenix pyrrhotite, but for Getrude West the effect was negligible [9]. Variation in pyrrhotite behaviour across deposits has been found attributable to its varying magnetisms, crystallography, and non-stoichiometric compositions of its mineralogy [9, 14].

Pentlandite itself, taken as $1.7 \mathrm{wt} \%$ in the feed, can be depressed or activated by $\mathrm{CuSO}_{4}$, depending on pulp chemistry [8]. In oxidizing pulp, copper hydroxide precipitates causing depression, while in reducing pulp, copper (II) can be reduced to copper (I), with sulphur oxidation, to produce $\mathrm{CuS}$ followed by $\mathrm{Cu}_{2} \mathrm{~S}$ on the pentlandite surface to achieve activation effect. This has also been observed with other sulphides-pyrite, sphalerite and pyrrhotite [7, 15-17].

From this background, it follows that the response of the ore sulphides to $\mathrm{CuSO}_{4}$ may not be readily predicted, but depends on various circumstances. Also, there is liberation constraint in this instance as the grind is constrained so that the pentlandite in pyrrhotite is not fully liberated. The presence of chalcopyrite can also affect how other sulphides actually respond. To see how the scenario affects 
the outcome, there can be very many variables to investigate separately, but a careful look at the effect of varying dosages of copper addition at established $\mathrm{pH}$ and grinding size should give a picture of the overall effect. The product fractions will be analysed to find how the different constituents respond with time. Recommendations can therefore be made with respect to the nickel interest.

\section{Materials and method}

\section{Ore sample collection and size analysis}

Milled ore sample used for the investigation was obtained from the BCL concentrator plant. The sample was collected at the cyclone overflow launder feeding the rougher flotation bank, using a sample cutter at $15 \mathrm{~min}$ intervals for a period of $2 \mathrm{~h}$. Each time a sample was cut, the density of the pulp was checked for consistency with a density gauge. The total slurry collected, about $33 \mathrm{~kg}$, was stirred and a sample was taken from the bucket, filtered and the residue dried. The dried sample was rolled to break any lumps and then split using a rotary splitter to get representative samples. Sieve analysis of the dry sample was done using $\sqrt{ } 2$ sieve series from 212 to $38 \mu \mathrm{m}$, to establish the feed particle size distribution (PSD) of the ore.

\section{Froth flotation}

The flotation investigations were done using a $2 \mathrm{~L}$ Denver cell at a pulp relative density of about 1.35 and impeller speed of $1200 \mathrm{rpm}$. The temperature ranged from 22.7 to $23.8^{\circ} \mathrm{C}$. The $\mathrm{pH}$ was maintained at about 9 using lime at the start of each float. In the base case conditioning without $\mathrm{CuSO}_{4}$ addition, treatment 1 (T1) was done using potassium normal butyl xanthate at $75 \mathrm{~g} /$ ton, at conditioning time of $3 \mathrm{~min}$. The other three treatments, T2, T3 and T4, were done with copper sulphate dosages of 15,30 and $45 \mathrm{~g} / \mathrm{ton}$, respectively, and the pulp conditioned for $5 \mathrm{~min}$ before adding the collector. In each flotation run, five concentrates, C1, C2, C3, C4 and C5, were separately collected over the respective time intervals between $0,1,3$, 6, 10 and $15 \mathrm{~min}$ of flotation. This will enable the kinetics of the response to be assessed for the different target contents. Each reagent condition was run in triplicate, the concentrate fractions and tailing for each run were dewatered, weighed and the mass pulls compared for procedural repeats. The fractions from every run were assayed for nickel, copper, iron and cobalt from hot aqua regia digestion using atomic absorption spectroscopy [18], with the residue considered essentially silica. From the assays, the mass pull and sink values, the feed grades were reconstituted for every run. Cumulative grades and recoveries were computed for the various constituents to analyse the responses to the treatments.

\section{Results and discussion}

The PSD analysis of the as-received samples gave $42 \%$, passing $75 \mu \mathrm{m}$. The responses of the different minerals to the flotation conditioning are discussed as follows. For a typical result of the floatation tests, Table 2 shows the data for the duplicate run for $\mathrm{T} 1$ (without activation) with the computation. Similar data and computation for the first and triplicate runs for T1, and T2-T4 runs, generate the overall charts discussed following.

\section{Nickel response}

Figures 1 and 2 show how nickel cumulative recovery and grade varied with time during the flotation for the varying dosages of the copper sulphate added to the pulp. The overall consideration shows that at $15 \mathrm{~g} /$ ton copper sulphate dosage, nickel recovery improved clearly by a maximum of about $6 \%$ without grade compromise. Looking at the details, the kinetics (Fig. 1) shows that in the first minute, nickel response was fastest without activation, giving the highest assay. This slowed down quickly and the cumulative grade dropped to the least for the treatments, while the final recovery was $88 \%$.

At $15 \mathrm{~g} /$ ton activation, the initial response appeared slower than that for no activation, but it was sustained over a longer period, so that the overall recovery clearly increased. The $30 \mathrm{~g} /$ ton condition followed a close pattern, but the overall recovery dropped a little while the assay increased. At $45 \mathrm{~g} /$ ton the result followed a different trend, with recovery lying lowest for all the duration, while cumulative assays ended highest. These trends are notable for insight into what is happening in the pulp after this conditioning. First, the conditioning reduced the kinetics of nickel response, but gave overall increased recovery. The overall response is obviously an indication of a composite response from different constituents. Certain constituent actually was floating very fast without the activation. The constituent perhaps still reported to the float, though at a slower rate, giving overall increase in recovery.

For the depression at the highest dosage, it implies that copper hydroxide predominates in this pulp at this concentration range. In a sphalerite collectorless flotation at $\mathrm{pH} \mathrm{8-10} \mathrm{[19],} \mathrm{recovery} \mathrm{was} \mathrm{observed} \mathrm{to} \mathrm{drop} \mathrm{from} \mathrm{above}$ $70 \%$ to below $20 \%$ with increase in $\mathrm{Cu}^{2+}$ concentration from $2 \times 10^{-6}$ to $2 \times 10^{-5} \mathrm{M}$. Using the instance of predominance diagram of copper in aqueous system shown in Fig. 3, the work showed that, with increasing 


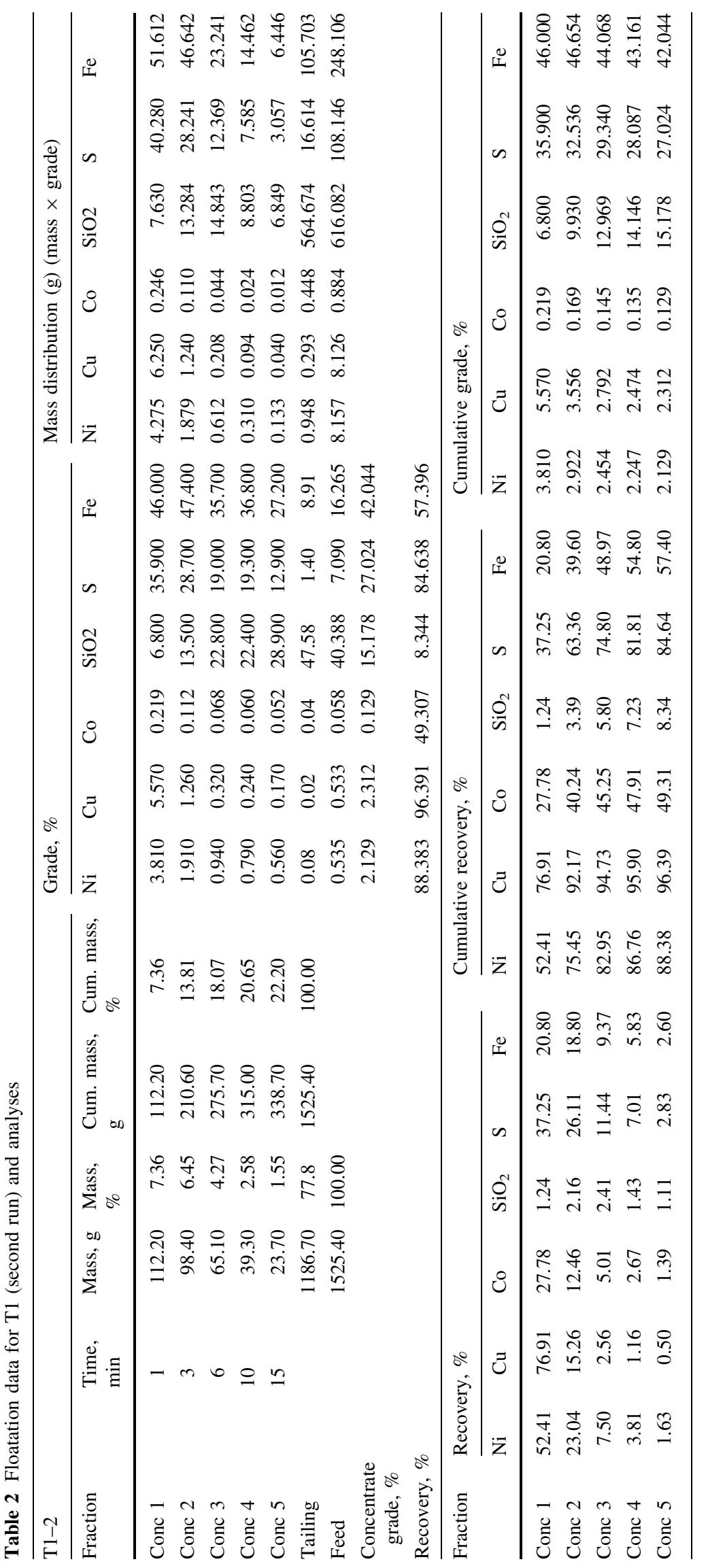


Fig. 1 Nickel cumulative a recovery and $\mathbf{b}$ grade over time at varying dosages of $\mathrm{CuSO}_{4}$

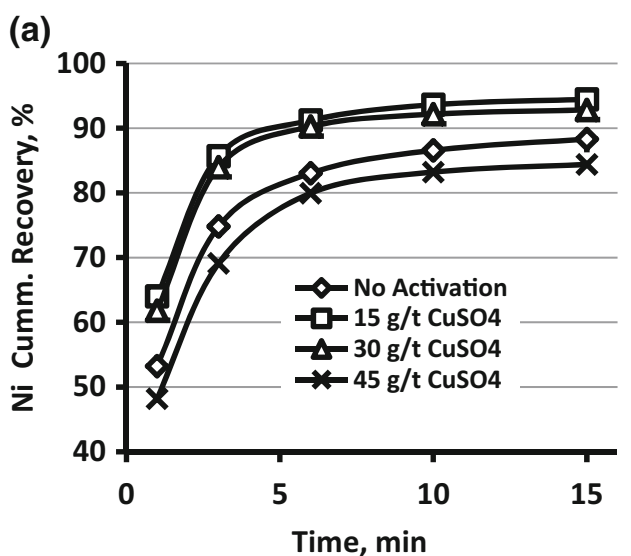

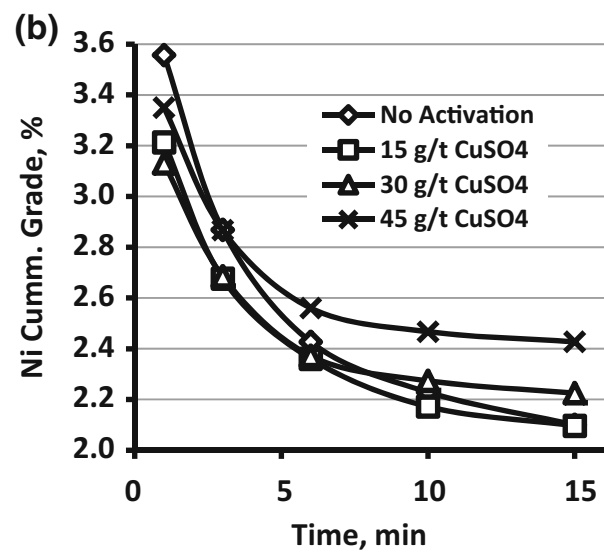

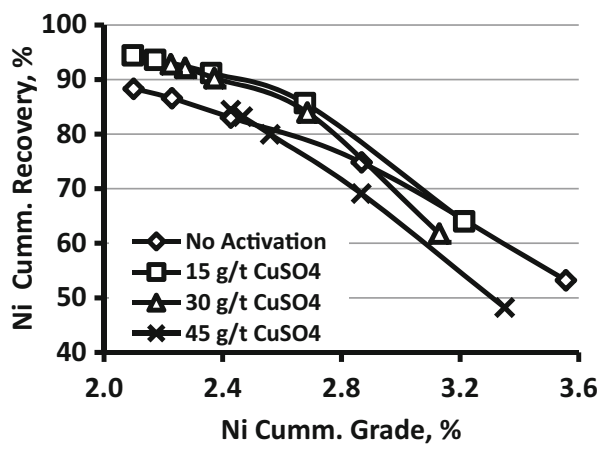

Fig. 2 Nickel cumulative recovery versus cumulative grade over time at varying dosages of $\mathrm{CuSO}_{4}$

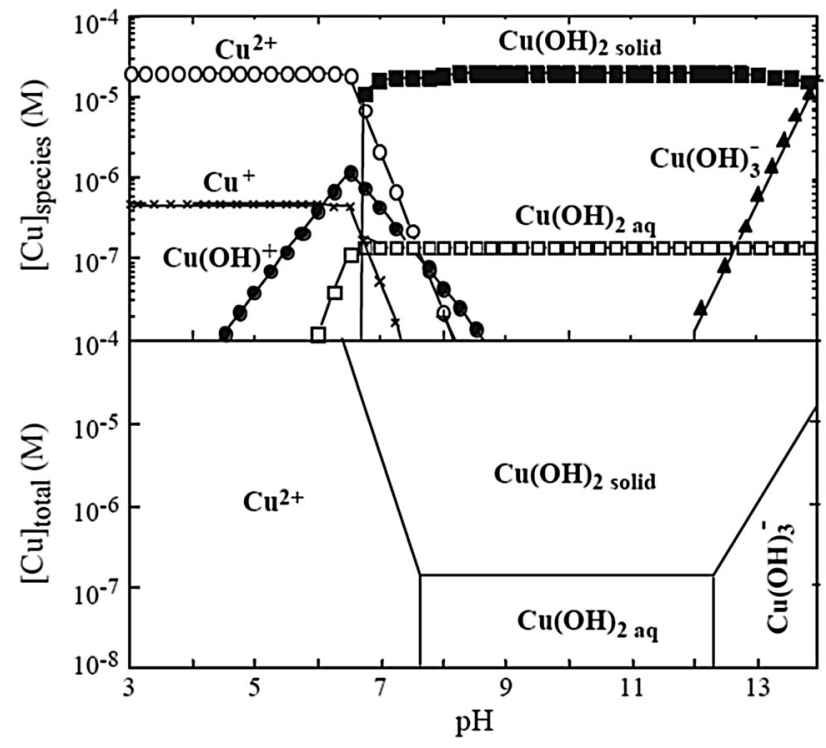

Fig. 3 Copper predominance area diagram at Eh $250 \mathrm{~V}$, SHE (below), with concentration of each copper species as a function of $\mathrm{pH}$ at a fixed total copper concentration of $2 \times 10^{-5} \mathrm{M}$ (on top) [16]

concentration, $\mathrm{Cu}^{2+}$ field reduces, while $\mathrm{Cu}(\mathrm{OH})_{2 \text { solid }}$ field expands over a wider $\mathrm{pH}$ range. Depending on $\mathrm{pH}, \mathrm{Cu}^{2+} \rightarrow$ $\mathrm{Cu}(\mathrm{OH})_{2 \text { solid }}$ or $\mathrm{Cu}(\mathrm{OH})_{2 \mathrm{aq}} \rightarrow \mathrm{Cu}(\mathrm{OH})_{2 \text { solid }}$ precipitation occurs [19]. Hence, copper hydroxide prevailed and sphalerite was decreased. In Figs. 1 and 2, depression at the highest $\mathrm{Cu}^{2+}$ dosage can therefore be attributed to increasing copper hydroxide predominance in the pulp at such a concentration range. However, increased recovery at lower dosage is clearly evident from the result, with best recovery at $94.5 \%$ at enrichment ratio of about 3.0. For an insight into how other components contributed to the recovery, the response of the other minerals, particularly pyrrhotite that contains substantial amount of the total nickel content, will be informative.

\section{Pyrrhotite response}

The $\mathrm{Fe}$ analysis shows that cumulative recovery increases by more than $10 \%$ with the addition of 15 and $30 \mathrm{~g} / \mathrm{ton}$ copper sulphate to the pulp (Fig. 4a). By $45 \mathrm{~g} /$ ton dosage, the cumulative recovery started dropping clearly, although $\mathrm{Fe}$ grade still increased with dosage up to this level (Fig. 4b). An optimum dosage therefore exists after which recovery will be traded off for grade. The observed depression is again attributable to copper hydroxide increasing predominance, such that only the most floatable grains were recovered at the higher dosages. The combined grade-recovery plot (Fig. 5) shows that the best dosage should not exceed $30 \mathrm{~g} / \mathrm{ton}$. Since the other ironbearing minerals contribute a relatively small amount of iron compared with pyrrhotite iron content in the ore (Table 1), it is obvious that that the conditioning activated pyrrhotite. The low recovery of pyrrhotite relative to pentlandite is understandable, because the inactivated pulp was optimized for pentlandite ab initio. Moreover, it is also known that pentlandite presence with pyrrhotite in a pulp can galvanically depress pyrrhotite. With Fourier transform infrared (ATR) spectroscopy, it was concluded that galvanic interactions in a pentlandite-pyrrhotite mixed mineral pulp enhance preferential formation of hydroxide on pyrrhotite and dixanthogen on pentlandite, which implies 
Fig. 4 Iron cumulative a recovery and $\mathbf{b}$ grade over time at varying dosages of $\mathrm{CuSO}_{4}$

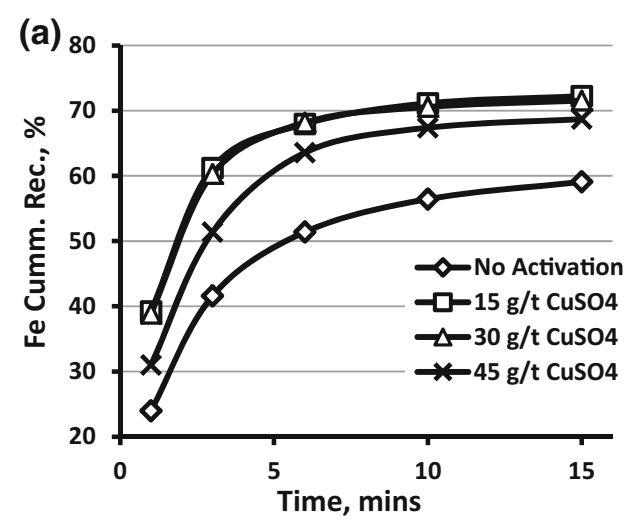

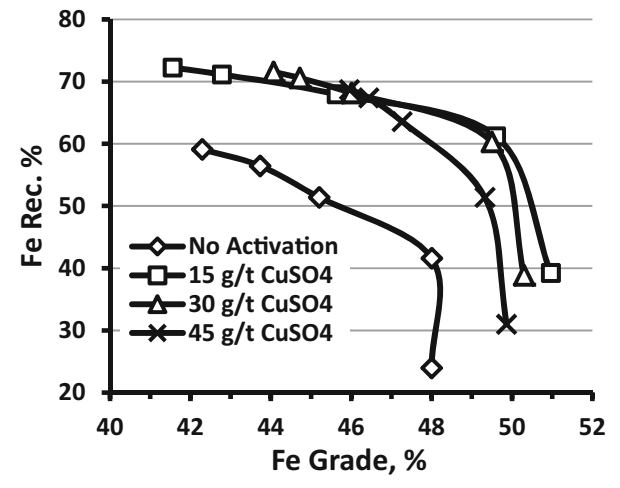

Fig. 5 Iron cumulative recovery versus cumulative grade over time at varying dosages of $\mathrm{CuSO}_{4}$

enhanced floatability of pentlandite at the expense of pyrrhotite in the same pulp [20]. With other flotation implications of the mineralogical differences, the recovery of the two minerals cannot be maximized in the same pulp and the extent of increase in recovery obtained here can be considered satisfactory.

Linking the pyrrhotite recovery to nickel recovery, with the $10 \%$ increase in pyrrhotite recovery after the conditioning, about a tenth more of the pentlandite in pyrrhotite was recovered. This also implies that there was about $1.4 \%$ increased recovery of the total nickel content, given that $14 \%$ of total nickel is in pyrrhotite (Table 1). At overall $72 \%$ highest recovery of pyrrhotite at enrichment ratio of 3.1 , about $4.2 \%$ of nickel will still be lost with pyrrhotite, except that flotation was selective of grains containing pentlandite, where partial exposure is possible. Further effort to recover more nickel will have to consider rougher tailing reconditioning to recover the pyrrhotite.

\section{Chalcopyrite response}

Although chalcopyrite recovery was good without activation (at $96 \%$ ), copper analysis shows that some increase in recovery (to $97.6 \%$ ) was still obtained at the $15 \mathrm{~g} /$ ton dosage with clearly better grade (Fig. 6a, b). At the higher dosages, recoveries dropped. By the $45 \mathrm{~g} /$ ton dosage level, recovery was well below the value obtained without activation. The copper grade was highest at the low recovery, indicating drop in mass pull, with only the most floatable grains going into the concentrate. At the highest recovery of $97.7 \%$, the grade was $3.5 \%$, indicating an enrichment ratio of 5.0.

\section{Cobalt recovery}

The cumulative recovery of cobalt increased from about $47 \%$ without activation to above $60 \%$ at the higher activation dosage, with assays about $0.11 \%$ (Fig. 7). Since cobalt is in solid solution in the pentlandite and improved recovery of the target sulphides was obtained, the increased recovery of cobalt is therefore normal and it is also proportionate.

\section{Silica entrainment}

Recovery and grades of silica under the treatments were assessed for an indication of the gangues response. At $15 \mathrm{~g} /$ ton copper sulphate dosage, final silica recovery in the flotation concentrate is above the recovery under the condition without copper addition (Fig. 8a). Since the cumulative grade of silica in the concentrate increased with flotation time all through (Fig. 8b), this recovery pattern characterizes entrainment [21, 22]. Since water recovery suffices to sustain entrainment, entrained matter forms the larger fraction of the mass pull after hydrophobic flotation response has subsided, explaining increasing silica grade with increasing recovery. At the higher copper sulphate dosages, the entrainment recovery reduced to lower values. This easily reconciles with the general depression observed for the $45 \mathrm{~g} / \mathrm{ton}$ dosage. 
Fig. 6 Copper cumulative recovery versus a time and b cumulative grade at varying $\mathrm{CuSO}_{4}$ dosages

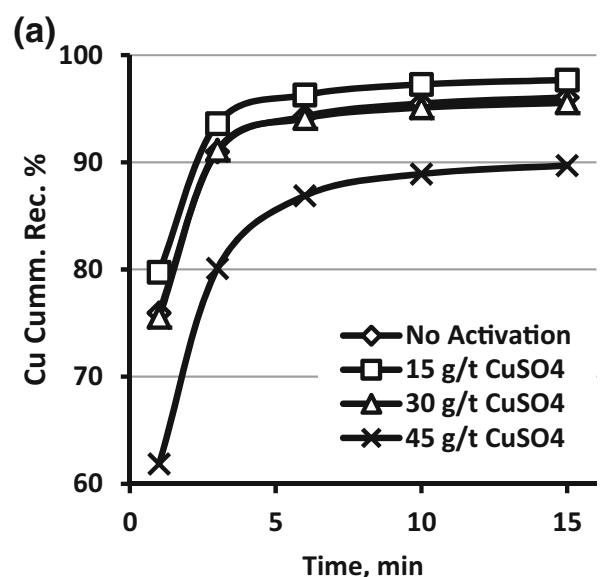

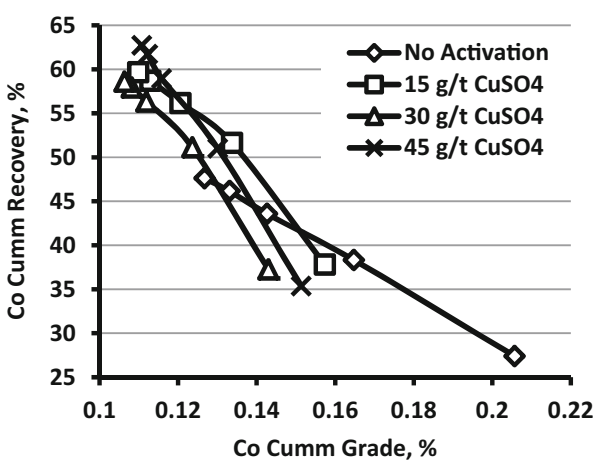

Fig. 7 Cobalt cumulative recovery versus cumulative grade at varying $\mathrm{CuSO}_{4}$ dosages

\section{Overall implication}

Combining the observations, it is obvious that copper sulphate addition to this pulp can achieve improved grade and recovery of the target values of nickel and copper. The dosage, however, has to be between 15 and $30 \mathrm{~g} /$ ton to optimize grade recovery. The depression after the optimum dosage of copper sulphate is obtained can be explained based on the change in the predominance of copper, from $\mathrm{Cu}^{2+}$ to $\mathrm{Cu}(\mathrm{OH})_{2}$. Hydrophilic $\mathrm{Cu}(\mathrm{OH})_{2}$ precipitates at the surface of sulphide grains and bring about depression with increase in the copper hydroxide species in the pulp. This frustrates formation of the metal polysulfide on the grains that needs activation, as well as xanthate interaction for all the sulphides, such that even chalcopyrite is depressed. About this optimum dosage, the $\mathrm{Fe}$ content in the concentrate will increase with pyrrhotite recovery. This is a necessary compromise to recover the nickel content in the pyrrhotite. However, the pyrrhotite recovery is still relatively low, as the recovery of pentlandite and pyrrhotite cannot be maximized in the same pulp.

\section{Conclusion}

Increased recoveries of nickel was obtained in the BCL concentrator Selebi-Phikwe pentlandite-pyrrhotite-chalcopyrite ore flotation up to a maximum copper sulphate dosage, above which depression was observed and recoveries fell below that for the condition without any copper addition. Nickel recovery with increasing copper sulphate
Fig. 8 Silica cumulative recovery versus a cumulative grade and $\mathbf{b}$ time at varying $\mathrm{CuSO}_{4}$ dosages (a)

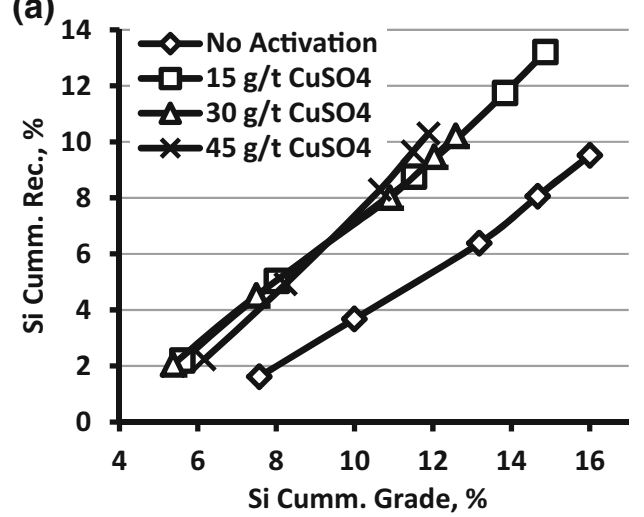

(b)

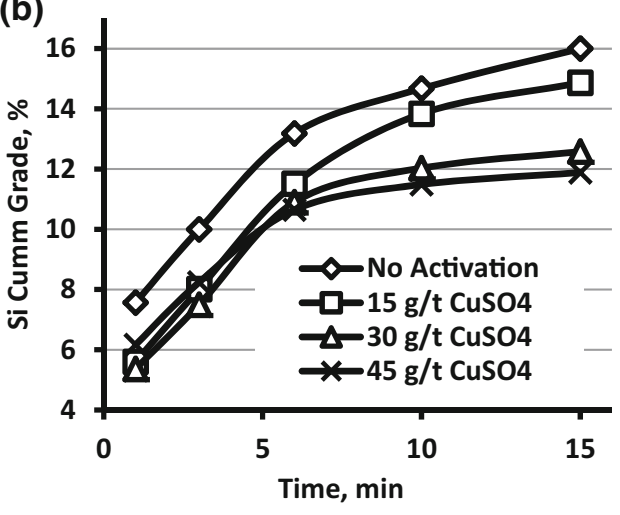


dosage therefore shows a maxima. A dosage range about this maxima dosage is the critical process parameter for successful activation of the ore with copper sulphate. The depression at higher dosage is explicable based on predominance change of copper with increasing concentration in the pulp. However, this increased recovery is with a compromise that pyrrhotite must be recovered along with pentlandite, due to dissemination constraints. Despite chalcopyrite presence, pyrrhotite recovery still improved, as chalcopyrite recovery also increased marginally. Because response to copper sulphate addition in flotation can vary from possible depression to activation in sulphide ores, it is notable in this ore that despite flotation constraints imposed by the mineralogy, activation with copper sulphate to increase nickel recovery can still be achieved, but within the careful dosage range.

Open Access This article is distributed under the terms of the Creative Commons Attribution 4.0 International License (http://crea tivecommons.org/licenses/by/4.0/), which permits unrestricted use, distribution, and reproduction in any medium, provided you give appropriate credit to the original author(s) and the source, provide a link to the Creative Commons license, and indicate if changes were made.

\section{References}

1. Mulaba-Bafubiandi AF, Medupe O (2007) An assessment of pentlandite occurrence in the run of mine ore from BCL mine (Botswana) and its Impact on the flotation yield. In: Proc. of the fourth Southern African conference on base metals, Swakopmund, Namibia, SAIMM, pp 57-76

2. Simwaka M, Gumbie M, Moswate P, Moroka M, Keitshokile DC, Dzinomwa G (2009) Milestones in the improvement of concentrator nickel. In: Proc. fifth base metal conference, Kasane, Botswana, SAIMM, pp 359-368

3. Tripathi N, Peek E, Stroud M (2011) Advanced process modelling at the BCL smelter: improving economic and environmental performance. JOM 63(1):63-67

4. NDP9 (2002) Mineral development. In: Botswana National Development Plant 9, Publication of Government of Botswana (online)

5. BCL (2011) Strategy, monitoring and evaluation. www.bcl.bw/ index.php?id=34. Assessed 10 Nov 2014

6. Finkelstein NP (1997) The activation of sulphide minerals for flotation: a review. Int J Miner Process 52:81-120

7. Chandra AP, Gerson AR (2009) A review of the fundamental studies of the copper activation mechanisms for selective flotation of the sulphide minerals, sphalerite and pyrite. Adv Colloid Interface Sci 145:97-110

8. Peng YJ, Seaman D (2012) Effect of feed preparation on copper activation in flotation of Mt Keith pentlandite. Miner Process Extr Metall Trans Inst Min Metall C 121(3):131-139

9. Ekmekçi Z, Becker M, BagciTekes E, Bradshaw E (2010) An impedance study of the adsorption of CuSO4 and SIBX on pyrrhotite samples of different provenances. Miner Eng 23:903-907

10. Senior GD, Shannon LK, Trahar WJ (1994) The flotation of pentlandite from pyrrhotite with particular reference to the effects of particle size. Int J Miner Process 42(3-4):169-190

11. Kelebek S, Wells PF, Fekete SO (1996) Differential flotation of chalcopyrite, pentlandite and pyrrhotite in ni-cu sulphide ores. Can Metall Q 35(4):329-336

12. Wiese JG, Harris PJ, Bradshaw DJ (2005) The influence of the reagent suite on the flotation of ores from the Merensky Reef. Miner Eng 18:189-198

13. Bradshaw DJ, Buswell AM, Harris PJ, Ekmekci Z (2006) Interactive effects of the type of milling media and copper sulphate addition on the flotation performance of sulphide minerals from Merensky ore Part I: pulp chemistry. Int J Miner Process 78:153-163

14. Becker M, de Villiers JPR, Bradshaw DJ (2008) Evaluation of pyrrhotite from selected Ni and PGE ore deposits and the influence of its mineralogy on flotation performance. In: 9th international congress for applied mineralogy, Brisbane, AusIMM, pp 401-409

15. Trahar WJ, Dunkin HH (1954) The effect of an excessive addition of copper sulphate on the flotation of sphalerite. In: Proceedings of the AusIMM 173:13-29

16. Clarke P, Fornasiero D, Ralston J, Smart RSC (1995) A study of the removal of oxidation products from sulphide mineral surfaces. Miner Eng 8:1347-1357

17. Dávila-Pulido GI, Uribe-Salas A, Nava-Alonso F (2012) Revisiting the chemistry and kinetics of sphalerite activation with $\mathrm{Cu}(\mathrm{II})$ : a contact angle study. Open Miner Process J 5:1-5

18. Willard Horbart H, Merritt LL, Dean JA, Settle Frank A (1988) Instrumental methods of analysis, 7th edn. Wardsworth Inc, California

19. Fornasiero D, Ralston J (2006) Effect of surface oxide/hydroxide products on the collectorless flotation of copper-activated sphalerite. Int J Miner Process 78:231-237

20. Bozkurt V, Xu Z, Finch JA (1998) Pentlandite/pyrrhotite interaction and xanthate adsorption. Int. J. Miner Process 52:203-214

21. Otunniyi IO, Groot DR, Vermaak MKG (2013) Particle size distribution and water recovery study under the natural hydrophobic response flotation of printed circuit board comminution fines. Miner Metall Process J 30(2):85-90

22. Zheng X, Franzidis JP, Johnson NW (2006) An evaluation of different models of water recovery in flotation. Miner Eng 19:871-882 